\title{
CORPORATE GOVERNANCE AND INTERNET FINANCIAL REPORTING IN INDONESIA (An Empirical Study on Indonesian Manufacturing Companies)
}

\author{
Abeir H. hezadeen ${ }^{1}$, Ali Djamhuri ${ }^{2}$, Yeney Widya ${ }^{3}$ \\ ${ }^{\prime}$ Master Program of Accounting, University of Brawijaya, Malang, Indonesia, \\ Libyan \\ ${ }^{2,3}$ Department of Accounting Science, Faculty of Economics and Business, University of \\ Brawijaya, Malang, Indonesia
}

\begin{abstract}
This study aims to investigate the effects of the corporate governance and ownership structure on the internet financial reporting in manufacturing companies in Indonesia. The variables used are internet financial reporting, board of director competence, board of director size, board of director meeting, audit committee independence, audit committee competence, audit committee size, audit committee activity, ownership concentration on Top 5 shareholder and number of shareholders. The results showed that board of director competency, board of director meeting, and audit committee competence have a positive effect on internet financial reporting. The results support institutional theory. However, board of director size shows affects negatively on internet financial reporting. On the other hand, other five (5) variables examined in this study namely audit committee independence, audit committee size, audit committee activity, ownership concentration on top 5 shareholders, and number of shareholders are not proven to affect the internet financial reporting. While the results of audit committee activity and ownership concentration on top 5 shareholders analysis support institutional theory, the results of audit committee independence, audit committee size, and number of shareholders do not support institutional theory.

Keywords: Internet Financial Reporting, Board of Director Competence, Board of Director Size, Board of Director Meeting, Audit Committee Independence, Audit Committee Competence, Audit Committee Size, Audit Committee Activity, Ownership Concentration on Top 5 Shareholder, Number of Shareholders.
\end{abstract}




\section{INTRODUCTION}

Currently, more and more companies from developed countries are providing their corporate financial information via their Web sites. Similarly, companies from emerging and developing countries have no choice but to follow this reporting trend. Internet financial reporting might be defined as the use of firms' websites to disseminate corporate financial and performance information (Wagenhofer, 2003). This is believed to be able to facilitate the process of firm's additional equity gathering efforts and increase information sharing through a new instrument. In economic perspective, the use of internet financial reporting has some advantages both for the adopters and beneficiary stakeholders, such as favorable changes regarding to the cost of information process and dissemination of financial information in capital markets. Moreover, it also helps to improve availability of financial information to all users and reduce time spent on responding information requests. Kelton and Yang (2008) proved that the internet has increased the transparency in the process of disseminating the financial statements.

In the context of Indonesia, there is a Limited Liability Company Act No. 40 year 2007 requiring companies in Indonesia to report their ongoing activities. However, so far Indonesia have not yet implemented specific regulations associated with the financial statement presentation over the internet.

According to Bipin, et. al., (2005), a sound corporate governance is needed to support a more transparent disclosure. As corporate governance mechanism aimed to ensure governance system within an organization, Kaihatu (2006) states that disclosure and transparency are important aspects in implementation of good corporate governance.

In addition, one of the dominant theoretical perspectives in organization theory is institutional theory. There are institutional differences exist between capital markets developed and developing countries such as Indonesia. These differences can affect how directors and managers run the company locally. Although, the internet has supported the development of financial reporting in the US and European countries, there is limited previous research examining the relationship between corporate governance structure and financial reporting of the internet in emerging markets such as Indonesia.

In addition, the influence of audit committee characteristics on the IFR (internet financial statement reporting) has been a major issue in Indonesian IFR studies in the past two decades. Even though there has not been any formal regulation of IFR implementation in Indonesia (Spica, 2008), Indonesian companies have started to adopt IFR according to certain motives. Based on Puspitaningrum and Atmini (2012), if corporate governance is complementary, companies will tend also to make voluntary disclosure. One way to do voluntary disclosure is by applying IFR.

The goal of this research is to analyze the internet financial reporting practices in Indonesian listed companies in relation with corporate governance and financial report. Therefore, the main objective of this research is to analyze the factors that influence the Internet financial reporting practices of Indonesian listed companies. The specific objectives are: 1) To analyze the relation between ownership concentration on top 5 shareholders, number of shareholders and the internet financial reporting; and 2) To analyze the relation between board of director competence, board of director size, board of director meeting, audit committee independence, audit committee competence, audit committee size, audit committee activity and the internet financial reporting. 


\section{LITERATURE REVIEW}

\section{Internet Financial Reporting}

Internet financial reporting can be defined as the use of the company's web site to disseminate financial information and company performance. IFR important element is the degree or quantity of disclosure (Ashbaugh et al., 1999). The higher the level of disclosure in the quantity or transparency is, the greater the impact of disclosure on investor decisions will be. More specifically, IFR has opened a new research domain in the areas of accounting and finance, but little is researching how IFR affects the stock. The size of the company (firm size) is the variable that most often appears as a factor affecting the IFR.

\section{Board of Director Competence}

The Board of Directors can only be effective when they have adequate financial and human resources, as well as members with the necessary experience, knowledge, skills and time to exercise their duties (IFC, 2014). Board experience will assist in making information more transparent as comparisons can be made base on knowledge of other organizations. Experienced directors are also more likely to have greater incentives to be effective monitors of management to safe guard their reputation or improve their external labor market (Abdelsalam and Street, 2007).

Related to that, Xiao et al., (2004) argue to increase organizational legitimacy; professional establishes standards to create homogeneous organizational practices such as Internet reporting. Abdelsalam and Street (2007) provided additional evidence of a significant association between the timeliness of corporate internet reporting and board experience. Therefore, it is clear that with the more competent boards of directors the companies will upload more information on the internet.

\section{Board of Director Size}

The size of the Board of Directors will need to be adapted to the specific circumstances of the company and, consequently, will vary in composition. It will dominantly depend on the activities of the company, size (number of employees), level of development and other characteristics of the company (IFC, 2014).

Research done by Gandia (2008) shows that board of director size would increase the disclosure because higher level of disclosure gives positive impression as it is of the board members' decision (Raheja, 2005). According to Yap et. al., (2011), Internet financial reporting is also associated with board of director size. Nevertheless, a larger group of board members may have poorer communication and the additional cost of inefficiencies in decision-making. Therefore, a bigger board size may reduce the controlling and monitoring capacities.

\section{Board of Director Meeting}

The intensity of board activities is likely to contribute to the effectiveness of oversight functions, especially relating to financial reporting. Conger et al., (1998) argue that board's effectiveness can be improved by duration of board meeting. It is expected that Internet financial reporting is positively related to more diligent boards measured by the board meetings number held during the financial year. Thus, it is assumed that the 
more frequently the meeting of the board of directors is held, the more the company will publish the report online.

\section{Audit Committee Independence}

The independence of auditors is the basis for the auditor and an important element in the process of reporting the company and the key prerequisites that add value to the audited financial statements (Ping et al., 2011). In addition, the independent auditing helps in crediting financial statements, guaranteeing reliability and approving the quality of financial information for the other beneficiaries. Moreover, the investors, creditors and other beneficiaries rely on the results of auditing carried out by the independent auditing institutions to assess the financial performance of the different business entities regarding different investment opportunities. Thus, the more auditing quality will result in more value, credibility and acceptability of it by the users of financial statements (Hoseinbeglou et al. 2013).

\section{Audit Committee Competence}

The audit committee members must possess two main competences including the knowledge on how business is presented in financial reports and the ability to analyze reporting (financial reporting knowledge), and the understanding of the nature and purpose of auditing the financial report (audit report knowledge). Velte and Stiglbauer (2011) stated that financial expertise of the audit committee members provide a basis for the reduction of information asymmetries between the management board and the audit committee and the respective agency costs.

Empirical evidence proves the financial expertise of audit committee increases the quality of financial reporting. The financial and governance expertise of the audit committee is positively related to perceived financial quality and Internet financial reporting (Kelton and Yang, 2008). Therefore, the researchers suggest audit committee financial expertise is related to disclosure transparency measured by Internet financial reporting.

\section{Audit Committee Size}

The Code of Corporate Governance (2000) also requires the audit committee to be comprised of at least three members. Raghunandan \& Rama (2007) argued that the size of audit committee increases the number of meetings. This increase in meeting frequency is argued to provide more effective monitoring. However, Vafeas (1999) argued that larger audit committee can lead to inefficient governance, because of yielding frequent meetings which leads to increased expenses. Kelton and Yang (2008) found that firms with a higher percentage of audit committee members that are considered financial experts are more likely to engage in IFR.

\section{Audit Committee Activity}

Abbott, et al. (2004) found that the frequency of meetings held in a year reflects the continuous engagement of the committee members in order to discuss any auditing related issues to help improvement. These results imply that audit committees that meet frequently are more diligent in the discharge of their duties. The audit committee 
normally should meet three to four times a year to carry out the obligations and responsibilities of the company's financial reporting system effectively.

Bronson et al., (2006) found the number of audit committee meetings is positively related to voluntary disclosure on internal controls in management reports. Kelton and Yang (2008) found that firms with a more diligent audit committee are more likely to engage in IFR. In addition, Puspitaningrum and Atmini (2012) reported that among the principles of corporate governance; ownership, independent commissioner and audit committee characteristics, only Audit committee meeting frequency that has an influence on voluntary disclosure IFR.

\section{Ownership Concentration on Top 5 Shareholder}

Evidence on the effect of ownership structure of the degree of disclosure of information is mixed. It is found that companies with diffused ownership are more likely to disclose more information on their web sites to keep their shareholders well informed (Kelton and Yang, 2008). Moreover, Wang et al. (2008) considers large stockholders to be the accounting information demanders and possess more power to govern and control quality of the accounting information.

In Indonesia concentration of ownership in most of public companies is in the hands of several families (Husnan, 2000). Thus, the researchers expect the concentrated companies to be less likely to disclose voluntary information on the Web. Based on the above discussion, companies with higher ownership concentration may be expected less likely to disclose voluntary information on Internet.

\section{Number of Shareholders}

Number of shareholders is measured by the log of the number of shareholders less the log of the mean number of shareholders of companies in the same asset decile (Sengupta, 2004).As the shareholders number increases, one would expect disclosure to increase. Companies with a larger shareholders number are more likely to voluntarily disclose more information to satisfy the information needs of diverse shareholders (Cooke, 1989). Yap et. al., (2011) reported that Internet financial reporting is positively associated with the numbers of shareholders.

\section{RESEARCH METHOD}

This research is a causal explanation because it tries to find the causal relationship between two or more variables as the characteristics of the problem. It uses a quantitative approach which emphasizes testing the theory by measuring the variables with numbers and analyzing data with statistical procedures.

The population in this study is public listed companies in the Indonesia Stock Exchange in 2015. Companies selected as a sample are the manufacturing companies which fulfill the criteria set by the researcher. These criteria are:

1. The companies are public listed manufacturing companies publishing their financial statements closing date December 31 in 2015.

2. The public listed companies have websites to share financial and nonfinancial information, not only to advertise their products

3. The website of the public listed companies is not under construction 
4. The public listed companies have all data needed in this research.

The method of data analysis used is multiple regressions. Before conducting the multiple regression analysis, there will be descriptive statistic analysis and some testing of classical assumptions.

\section{FINDINGS AND DISCUSSION}

Descriptive statistics of the data of the 137 manufacturing companies listed on Indonesian Stock Exchange in 2015 are presented in the following Table 1.

Table 1. Descriptive Statistic

\begin{tabular}{|c|c|c|c|c|c|c|}
\hline $\begin{array}{l}\text { Variable } \\
\text { Name }\end{array}$ & $\begin{array}{l}\text { Variable } \\
\text { Symbol }\end{array}$ & $\mathbf{N}$ & Minimum & Maximum & Mean & $\begin{array}{c}\text { Std. } \\
\text { Deviation }\end{array}$ \\
\hline $\begin{array}{c}\text { Ownership } \\
\text { Concentration on Top } \\
5 \text { Shareholder }\end{array}$ & TOP5 & 137 & 0.33 & 0.99 & 0.74 & 0.15 \\
\hline $\begin{array}{c}\text { Number of } \\
\text { Shareholders }\end{array}$ & SHNO & 137 & 2 & 14 & 4.78 & 2.42 \\
\hline $\begin{array}{l}\text { Board of Director } \\
\text { Competency }\end{array}$ & $\mathrm{BC}$ & 137 & 0.00 & 1.00 & 0.60 & 0.22 \\
\hline Board of Director Size & BS & 137 & 2 & 15 & 4.99 & 2.24 \\
\hline $\begin{array}{c}\text { Board of Director } \\
\text { Activity }\end{array}$ & BA & 137 & 2 & 58 & 16.16 & 11.38 \\
\hline $\begin{array}{l}\text { Independence audit } \\
\text { committee }\end{array}$ & $\mathrm{ACI}$ & 137 & 0.25 & 0.50 & 0.33 & 0.04 \\
\hline $\begin{array}{l}\text { Audit committee } \\
\text { activity }\end{array}$ & ACA & 137 & 2 & 22 & 5.75 & 3.61 \\
\hline $\begin{array}{l}\text { Audit Committee } \\
\text { Competency }\end{array}$ & $\mathrm{ACC}$ & 137 & 0.50 & 1.00 & 0.98 & 0.07 \\
\hline Audit Committee Size & ACS & 137 & 2 & 4 & 3.04 & 0.31 \\
\hline $\begin{array}{c}\text { Internet Financial } \\
\text { Reporting }\end{array}$ & IFR & 137 & 0.22 & 0.76 & 0.53 & 0.09 \\
\hline
\end{tabular}

The result of Multiple Regressions and Hypothesis Testing is shown in Table 2.

Table 2. Multiple Regressions and Hypothesis Testing

\begin{tabular}{|c|c|c|c|c|c|c|c|}
\hline \multirow[t]{2}{*}{$\begin{array}{l}\text { Number of } \\
\text { Hypothesis }\end{array}$} & \multirow{2}{*}{ Model } & \multicolumn{2}{|c|}{$\begin{array}{c}\text { Unstandardized } \\
\text { Coefficients }\end{array}$} & \multirow{2}{*}{$\begin{array}{c}\text { Standardized } \\
\text { Coefficients } \\
\text { Beta }\end{array}$} & \multirow{2}{*}{$\mathrm{t}$} & \multirow{2}{*}{ Sig. } & \multirow{2}{*}{$\begin{array}{c}\text { Hypothesis } \\
\text { Testing } \\
\text { Results }\end{array}$} \\
\hline & & B & $\begin{array}{l}\text { Std. } \\
\text { Error }\end{array}$ & & & & \\
\hline & (Constant) & .212 & .232 & & .913 & .363 & \\
\hline 1 & TOP5 & -.027 & .049 & -.044 & -.542 & .589 & Rejected \\
\hline 2 & SHNO & .003 & .003 & .075 & .954 & .342 & Rejected \\
\hline
\end{tabular}




\begin{tabular}{|c|c|c|c|c|c|c|c|}
\hline 3 & $\mathrm{BC}$ & .085 & .036 & .200 & 2.395 & .018 & Accepted \\
\hline 4 & $\mathrm{BS}$ & .011 & .003 & .271 & 3.364 & .001 & Accepted \\
\hline 5 & BA & .002 & .001 & .245 & 3.020 & .003 & Accepted \\
\hline 6 & $\mathrm{ACI}$ & -.171 & .295 & -.069 & -.578 & .564 & Rejected \\
\hline 7 & $\mathrm{ACA}$ & .000 & .002 & .008 & .092 & .927 & Rejected \\
\hline 8 & $\mathrm{ACC}$ & .244 & .107 & .192 & 2.290 & .024 & Accepted \\
\hline 9 & $\mathrm{ACS}$ & .001 & .037 & .003 & .026 & .980 & Rejected \\
\hline \multicolumn{8}{|c|}{ Adjusted R } \\
\hline & $\mathrm{R}$ & \multicolumn{2}{|c|}{ R Square } & & \multicolumn{2}{|l|}{$\mathrm{F}$} & Sig. \\
\hline & .498 & \multicolumn{2}{|c|}{.248} & .195 & \multicolumn{2}{|c|}{4.651} & $.000^{\mathrm{a}}$ \\
\hline
\end{tabular}

The model of the multiple regressions can be applied with model as follows:

$$
\begin{aligned}
\mathrm{IFR}= & \beta 0+\beta 1 \text { Top5it }+\beta 2 \text { SHNo5it }+\beta_{3} \text { BCit }+\beta_{4} \text { BSizeit }+\beta 5 \text { BAit }+\beta 6 \text { ACIit }+ \\
& \beta \text { 7ACCit }+\beta 8 \text { ACAit }+\beta \text { ACSit } \varepsilon
\end{aligned}
$$

From the F test obtained F value on Internet Financial Reporting is 4.651 with significant values of 0.000 . The significant values was less than 0.05 , so the regression model can be used to predict Internet Financial Reporting or it can be said that Board Competency, Board Size, Board Activity, Independence audit committee, Audit committee activity, Audit Committee Competency, Audit Committee Size, Ownership Concentration on Top 5 Shareholders, and Number of Shareholders affect simultaneously the variation of Internet Financial Reporting.

Adjusted table shows the value of 0.248 on Internet Financial Reporting. The Board Competency, Board Size, Board Activity, Independence audit committee, Audit committee activity, Audit Committee Competency, Audit Committee Size, Ownership Concentration on Top 5 Shareholders and Number of Shareholders can explain the variations in dependent variables. The variation in the Internet Financial Reporting by variation shows that adjusted $\mathrm{R}^{2}$ only $24.8 \%$. This indicates that $24.8 \%$ of the variance in the dependent variable is explained by the independent variables. Therefore, the regression model is adequate to explain the relation. Moreover, the $\mathrm{F}$ test shows significance at $4 \%$ level.

The results showed that the testing of the hypothesis $1(\mathrm{H} 1)$ which states that ownership concentration on Top 5 negatively influences the Internet Financial Reporting does not show a significant relation. There is not any relation between ownership concentration on Top 5 and internet financial reporting. Thus, the hypothesis 1 is rejected. According to the multiple regression analysis, the results showed that the sig value of 0.589 is $>0.05$. It means that the ownership concentration on top 5 shareholders is not significant at the $5 \%$ level. Thus, the ownership concentration on top 5 shareholders fails to guarantee the disclosure of financial reporting on internet, This result is consistent with findings of Abdelsalam and Street (2007). However, this result is inconsistent with Kelton and Yang (2008) who was significant negative relationship.

The hypothesis 2 (H2) which states that number of shareholders positively influences the Internet Financial Reporting does not show a significant relation. There is 
not any relation between number of shareholders and internet financial reporting. Thus, the hypothesis 2 is rejected. According to the multiple regression analysis, the results showed that the sig value of 0.342 is $>0.05$. It means that the number of shareholders is not significant at the $5 \%$ level. Thus, the number of shareholders fails to guarantee the disclosure of financial reporting on internet.

The hypothesis $3(\mathrm{H} 3)$ which states that Board of Director Competence positively influences the Internet Financial Reporting shows a significant relation. There is a positive relation between board of director competence and internet financial reporting. Thus, the hypothesis 3 is accepted. According to the multiple regression analysis, the results showed that the sig value is $<0.05$. It means that the variable Board of Director Competence is significant at the $5 \%$ level. The $\mathrm{B}$ value of 0.085 indicates that the board of director competence affects on the $8 \%$ disclosure through internet financial reporting. Thus, as hefty $60 \%$ of the board of directors in Indonesian manufacturing companies have competency in accounting, it influences the disclosure of information on the websites.

The hypothesis 4 (H4) which states that board of director size negatively influences the Internet Financial Reporting shows a significant relation. There is a negative relation between board of director size and internet financial reporting. Thus, the hypothesis 4 is accepted. According to the multiple regression analysis, the results showed that the sig value of 0.001 is $<0.05$. It means that the variable board of director size is significant at the $5 \%$ level. The B value of 0.011 indicates that the board of director size affects on the $11 \%$ disclosure of internet financial reporting. Thus, the fact that the manufacturing companies in Indonesia per 2015 have followed the requirement stated in the ICL Article 92 which regulates that the board of directors of a company shall consist of 1 (one) or more members (IFC, 2014), especially, at least 2 (two) members of the board of directors in public companies influences the disclosure of information on the websites.

The hypothesis 5 (H5) which states that board of director meeting positively influences the Internet Financial Reporting shows a significant relation. There is a positive relation between board of director meeting and internet financial reporting. Thus, the hypothesis 5 is accepted. According to the multiple regression analysis, the results showed that the sig value of 0.003 is $<0.05$. It means that the variable board of director meeting is significant at the $5 \%$ level. The $\mathrm{B}$ value of 0.002 indicates that the board of director meeting affects on the $2 \%$ disclosure of internet financial reporting. The board of directors in manufacturing companies in Indonesia holds approximately 16 meetings annually. The positive influence means that the frequent meetings that are held by board of directors in manufacturing companies in Indonesia make the possibility of internet disclosure high.

The hypothesis 6 (H6) which states that audit committee independence negatively influences the Internet Financial Reporting does not show a significant relation. There is not any relation between audit committee independence and internet financial reporting. Thus, the hypothesis 6 is rejected. According to the multiple regression analysis, the results showed that the sig value of 0.564 is $>0.05$. It means that the independence audit committee is not significant at the $5 \%$ level. Thus, even though manufacturing companies in Indonesia has fulfilled the requirement to have at least one independent 
audit committee, the Independence of the audit committee does not have any relationship with the company. Therefore, this member fails to guarantee the disclosure of financial reporting on internet.

The hypothesis $\mathrm{H} 7$ (H7) which states that audit committee competence positively influences the Internet Financial Reporting shows a significant relation. There is a positive relation between audit committee competence and internet financial reporting. Thus, the hypothesis 5 is accepted. According to the multiple regression analysis, the results showed that the sig value of 0.024 is $<0.05$. It means that the variable board of director meeting is significant at the $5 \%$ level. The B value of 0.244 indicates that the audit committee competence affects on the $24 \%$ disclosure of internet financial reporting.

The hypothesis 8 (H8) which states that audit committee size positively influences the Internet Financial Reporting does not show a significant relation. There is not any relation between audit committee size and internet financial reporting. Thus, the hypothesis 8 is rejected. According to the multiple regression analysis, the results showed that the sig value of 0.980 is $>0.05$. It means that the size of audit committee is not significant at the $5 \%$ level. Thus, the number of members of audit committee fails to guarantee the disclosure of financial reporting on internet.

The hypothesis 9 (H9) which states that audit committee activity positively influences the Internet Financial Reporting does not show a significant relation. There is not any relation between audit committee activity and internet financial reporting. Thus, the hypothesis 9 is rejected. According to the multiple regression analysis, the results showed that the sig value of 0.927 is $>0.05$. It means that the audit committee activity is not significant at the 5\% level. Thus, the number of meetings that audit committee holds annually fails to guarantee the disclosure of financial reporting on internet. It can be said that although they have fulfilled the required number of meeting within a year, there may be no continuous engagement with the members of the committee to discuss any related issues for continuous improvement. Moreover, the meetings may not discuss the disclosure of financial statement on websites. Consequently, there are still items of financial report submission even though they have held regular meeting.

\section{CONCLUSIONS}

Main results from the regression model show Internet financial reporting is positively significantly related to board of director competence, board of director meeting and audit committee competence. However, the negative effect of board of director size on the internet financial reporting, The result supports the institutional theory mentioning that organizations should follow the rules.

On the other hand, the negative effect of audit committee independence , ownership concentration on Top 5 shareholders on the internet financial reporting, positive effect of audit committee size, audit committee activity, number of shareholders on the internet financial reporting are rejected as the results are not significant. The results of audit committee independence, audit committee size, and number of shareholders do not support institutional theory, while the results of audit 
committee activity and ownership concentration on Top 5 shareholders support institutional theory.

\section{Limitation}

In the data gathering process, it was found that there were some manufacturing companies which did not provide clear details of the number of shareholders and concentration on the top 5 shareholders. Therefore, not all manufacturing companies could be used as the sample of this research. As the consequence, the results may be affected by the limited number of observations. However, even though this study only focuses on the context of Indonesia the adjusted $\mathrm{R}^{2}$ in multiple regression analysis is $24.8 \%$ which means that the multiple regression model, which contained nine variables, explains about of the variation in the internet financial reporting and disclosure. it means that other variables that were not included could affect the level of disclosure (Yap et al., 2011).

\section{Recommendation}

For future research, it is suggested to find the other factors of corporate governance characteristics or structures in Indonesia's Code of Good Corporate Governance (2006) and internet information criteria as variables in investigating the relation between corporate governance and the internet financial reporting. Moreover, the government should make the internet financial reporting compulsory for all manufacturing companies in Indonesia for future development of the country economy and investment. 


\section{REFERENCES}

Abbott, J; Parker, S \& Peters, G. (2004). Audit committee characteristics and restatements. Auditing: A Journal of Practice and Theory, 23(1), 69-87.

Abdelsalam, O.H., and Street D.L. (2007). Corporate governance and the timeliness of corporate internet reporting by UK listed companies. Journal of International Accounting, Auditing, and Taxation, 16, 111-13.

Ashbaugh, H., K. Johnstone, and T. Warfield. (1999). "Corporate Reporting on the Internet". Accounting Horizons 13(3), 241-257.

Bipin, S.; Bhojraj, and Sengupta, P, (2005). The association between outside directors, institutional investors and the properties of management earnings forecasts. Journal of Accounting Research, 43, 343-376.

Bronson, S.N., J.V. Carcello and K. Raghunandan, (2006). Firm Characteristics and Voluntary Management Reports on Internal Control. Auditing, 25(2), 25-39.

Conger, J.A., D. Finegold and E.E. Lawler III, (1998). Appraising Boardroom Performance. Harvard Business Review, 76(1): 136-148

Cooke, S., (1989). Disclosure in the Corporate Annual Reports of Swedish Companies. Accounting and Business Research, 19, 113-122.

Gandia, J.L., (2008). Determinants of Internet-based Corporate Governance Disclosure by Spanish Listed Companies. Online Information Review, 32(6): 791-817.

Hoseinbeglou, S., Masrori, R. and A. Asadzadeh, 2013. The effect of corporate governance mechanisms on audit quality. J. Basic. Appl.Sci Res. 3(1): 891-897

Husnan, S. (2000). Corporate Governance in Indonesia, the Asian Development Bank. IFC. (2014). The Indonesian Corporate Governance Manual. First Edition. Jakarta: IFC.

Kaihatu, T. S. (2006). Good corporate governance dan penerapannya di Indonesia. Jurnal Manajemen dan Kewirausahaan, 8 (1): 1-9.

Kelton, A. S. and Yang, Y . (2008). The impact of corporate governance on Internet financial reporting, Journal of Accounting and Public Policy. 27, 62-87.

Ping Y., Elizabeth C. \& Roger S., (2011). Threats to auditor independence: The impact of relationship and economic bonds. Auditing: A Journal of Practice \&Theory, 30(1), 1211-148.

Puspitaningrum, D and Atmini, S. (2012). Corporate governance mechanism and the level of internet financial reporting: Evidence from Indonesian companies. Procedia Economics and Finance, 2: 157 - 166.

Raghunandan, K., \& Rama, D. V. (2007). Determinants of audit committee diligence. Accounting Horizons, 21(3), 265-279.

Raheja, G.C., (2005). Determinants of Board Size and Composition: A Theory of Corporate Boards. Journal of Financial and Quantitative Analysis, 40(2): 283306.

Sengupta, P. (2004). Disclosure timing: Determinants of quarterly earnings release dates. Journal of Accounting and Public Policy, 23, 457-482.

Spica, A. L. (2008). Faktor-faktor yang mempengaruhi pengungkapan sukarela Internet Financial and Sustainibility Reporting, Jurnal Akuntansi dan Auditing Indonesia, 12: 117-131. 
The National Committee for Corporate Governance (NCCG). (2000). the Indonesian Code of Corporate Governance.

Vafeas, N. (1999). Board Meeting Frequency and Firm Performance. Journal of Financial Economics, vol. 53, no. 1, pp. 113-42.

Velte, P. and Stiglbauer, M. (2011). Impact of audit committees with indpendent financial experts on accounting quality. An emphirical analysis of the German capital market. Problems and Perspectives in Management, 9 (4): 17-33.

Wagenhofer, A. (2003). Economic Consequences of Internet Financial Reporting. Schmalenbach Business Review, 55: 262-279.

Wang, K., Sewon, O. and Claiborne, M.C. (2008). Determinants and consequences of voluntary disclosure in an emerging market: Evidence from China. Journal of International Accounting, Auditing and Taxation; 17, pp. 14-30.

Xiao, J.Z., H. Yang and C.W. Chow, (2004). The Determinants and Characteristics of Voluntary Internet-Based Disclosures by Listed Chinese Companies. Journal of Accounting and Public Policy, 23: 191-225.

Yap, K., Sale, Z, and Abbesi, M. (2011). Internet Financial Reporting and Corporate Governance in Malaysia. Australian Journal of Basic and Applied Sciences, 5(10): 1273-1289, 2011. 